\title{
Preventing Sexual Violence on College Campuses: An Investigation of Current Practices of Conducting Background Checks on Student-Athletes
}

\begin{abstract}
Alicia Cintron, Jeffrey Levine, and Kristy McCray*
Instances of sexual violence against women on college campuses is a major concern for university administrators. One approach to reducing instances of sexual violence on college campuses has been conducting background checks with more focused attention on student-athletes, though this approach is not without risk. Therefore, the purpose of this study was to investigate current practices of conducting background checks on student-athletes, and to present risk management strategies to reducing sexual violence on campus. Through a systematic data collection approach that included Freedom of Information Act (FOIA) requests of NCAA Division I public institutions, we found the implementation of background checks for studentathletes is a widely accepted practice, where policies were mandated by the athletic conference, state administrative law, or within the university. Recommendations for addressing sexual violence on campus include comprehensive sexual violence prevention education for students and student-athletes, including bystander intervention training. Additionally, if schools opt to utilize background checks, policies and procedures must be created to ensure due process, consistency for admissions, and staff training.
\end{abstract}

Keywords: background checks, intercollegiate athletics, policy, student-athletes, higher education

\section{Introduction}

Sexual violence against women remains a major area of concern on college campuses. The college experience is defiled for many women, as research suggests as many as one in five women experience an attempted or completed sexual assault during their collegiate careers (Beaver, 2017; Black et al., 2011; Krebs, Lindquist, Warner, Fisher, \& Martin, 2007; National Institute

\footnotetext{
* Alicia Cintron, PhD, is an assistant professor of sport administration in the School of Human Services at the University of Cincinnati; email: alicia.cintron@uc.edu. Jeffrey Levine, PhD, JD, is an assistant clinical professor of sport management at Drexel University; email: jfl82@drexel.edu. Kristy McCray, PhD, is an assistant professor in the Department of Health and Sport Sciences at Otterbein University; email: kmccray@otterbein.edu.
} 
for Justice, 2010). A number of studies have shown anywhere between $10 \%$ and $26 \%$ of college females experienced some form of nonconsensual sexual contact during their college careers (Beaver, 2017). These alarming statistics has prompted a much-needed conversation about how to reduce violence against women on college campuses. One specific area of focus surrounds the world of athletics. Unfortunately, college sports is rampant with examples of sexual misconduct, assault, and violence against women. For example, former Florida State University football player and Heisman Trophy winner Jameis Winston was accused of sexual assault in 2012. Though he was not criminally charged, the victim filed a civil suit against him, which was later settled out of court. In 2016, after finishing his rookie season with the National Football League's (NFL) Tampa Bay Buccaneers, Winston was accused of groping a female Uber driver and served a three-game suspension in 2018 (Reyes, 2018).

At Baylor University, widespread complaints of sexual misconduct and violence by its football players were filed, and mostly ignored, by coaches and athletic and university administration, eventually leading to many arrests, convictions, and resignations across the university (Ladika, 2017). Brock Turner, a former swimmer at Stanford University, served only half of a six-month sentence he received after being convicted for sexually assaulting an unconscious woman (Ladika, 2017). Finally, in addition to decades of sexual abuse by now-convicted and former university physician Larry Nassar, Michigan State University (MSU) remains in the hot seat. Widespread accusations of sexual misconduct by MSU athletes rocked the university in early 2018 (Lavigne \& Noren, 2018) and, instead of helping the victims, evidence of a cover-up effort by university officials has come to light (Gibbs, 2018). These examples illustrate that sexual violence among athletes continues to be a major issue in the workplace, on college campuses, and in society. Further, USA Today found that at least 28 current and former athletes who have transferred schools since 2014 had been disciplined for a sexual offense at another institution (Jacoby, 2019).

While the matter of sexual violence involving athletes has been prevalent in the news cycle, considerable attention has also been on college campuses overall. The number of women who experience some form of sexual assault or violence on campus is significant (Beaver, 2017). In this era of the \#MeToo movement, sexual misconduct, sexual harassment, and sexual assault may be used interchangeably or regularly. Sexual misconduct is not a criminal trespass, though many universities have implemented a "sexual misconduct policy," ranging from cyber stalking to physical abuse (Baker, 2016). In 2001, the Office for Civil Rights (OCR; 2001) indicated that sexual harassment was conduct of a sexual nature "sufficiently serious that it adversely affects" students on campus (p. vi). Though serious, sexual harassment also does not constitute criminal trespass. In comparison, sexual assault includes a variety of physically abusive actions, many of which are punishable through the legal system. Definitions vary per a jurisdiction's penal code, but according to the Centers for Disease Control and Prevention (CDC), sexual assault is an umbrella term that encompasses all "sexual acts committed against someone without that person's freely given consent or refuse" (Basile, Smith, Breiding, Black, \& Mahendra, 2014, p. 11).

The effects of sexual violence can be dangerous and devastating. College women who have experienced sexual assault were more likely than their 
non-victimized peers to engage in drinking and driving, binge drinking, marijuana usage, and suicidal ideation (Brener, McMahon, Warren, \& Douglas, 1999). Victims are more likely than non-victims to report difficulty sleeping, activity limitations, chronic pain, and frequent headaches (Black et al., 2011). The high numbers of female victims as well as these debilitating and often lifelong effects are prompting a much-needed conversation on how to reduce sexual violence on college campuses.

A recent surge of demands for additional policies addressing athletes with a record of sexual violence partially stemmed from news that an Oregon State University baseball player was recruited and played for the Beavers despite a previous sexual violence conviction as a minor (Giambalvo, 2017). Students, the media, and advocates of sexual assault victims have demanded universities and the National Collegiate Athletic Association (NCAA) create specific polices for curbing instances of sexual violence by student-athletes (NCAA, 2017). For example, the student body at Washington State University addressed their concerns regarding student-athletes and sexual violence by requesting the university adopt a policy against recruiting athletes with a history of sexual violence (Giambalvo, 2017). Similarly, in 2017, eight United States Senators led by Senator Ron Wyden (D-OR), including notable voices such as Kirsten Gillibrand (D-NY) and former senator Al Franken (D-MN), implored the NCAA to adopt uniform policies for addressing recruited and transfer athletes who have a history of sexual violence (Dodd, 2017). In response, the NCAA has made strides towards addressing the issues surrounding sexual violence and student-athletes. For example, the NCAA Board of Governors created the NCAA Commission to Combat Sexual Violence (CCSV) in 2016 to "proactively examine issues and propose solutions related to what athletics departments, conferences and the national Association could do to address campus sexual violence to achieve positive culture change" (NCAA, n.d., para. 1). In 2017, upon the CCSV's recommendation, the NCAA membership adopted a sexual violence policy that requires coaches, student-athletes, and athletic administrators to complete sexual violence prevention education every year, with university administration verifying the completion of the training (NCAA, 2017). Unfortunately, the CCSV has since been disbanded (Jacoby, 2019). In 2019, eight U.S. Senators, including Amy Klobuchar (D-MN) and Ed Markey (D-MA), and again led by Senator Ron Wyden (D-OR), sent a letter to commissioners of the "Power Five" NCAA conferences requesting each take serious steps to remedy sexual violence within each conference members' athletic department (Rittenberg, 2019). The letter also questioned the CCSV's inability to address the policies that allow student-athletes to transfer to other universities despite having a history of misconduct (Wyden et al., 2019). According to a study done by USA Today, at least 28 current or former athletes who have faced disciplinary actions for sexually based offenses were able to transfer to other universities and athletic programs (Jacoby, 2019). Further progress in this area remains necessary.

Media discourse surrounding instances of student-athletes committing acts of sexual violence has guided the conversation towards reform. Much of the discussion on reform has been directed toward student-athletes, a decision that can be supported by research that suggests student-athletes are more prone to committing acts of sexual violence (Boeringer, 1996, 1999; Forbes, Adams-Curtis, Pakalka, \& White, 2006; Frintner \& Rubinson, 1993; Koss \& Gaines, 1993; 
McCray, 2015; McMahon, 2011; Murnen \& Kohlman, 2007; Young, Desmarais, Baldwin, \& Chandler, 2017). On the other hand, studies have also found that certain characteristics such as competitiveness may contribute to the propensity to commit an act of sexual violence and is not solely based on athletic participation (Caron, Halteman, \& Stacy, 1997). Additionally, reports of sexual violence involving student-athletes on college campuses tend to be reported by the media more often due to the elevated status of athletes (Caron et al., 1997; Coakley, 2009; Melnick, 1992). While student-athletes have been found to be perpetrators of sexual violence on campus and elsewhere, these instances are not unique to athletes. According to Smith and Stewart (2003), media speculation and academia may be oversimplifying the evidence suggesting athletes are more likely to commit acts of sexual violence than non-athletes.

In the attempt to maintain a safe and welcoming campus, one approach to reducing the number of instances of sexual violence is vetting prospective students through the implementation of some form of background check. Background checks, whether formal through a third-party company or informal through self-disclosure, can shed light on a prospective student's history, specifically when addressing issues of violence, sexual violence, and academic misconduct (Stavenhagen, 2017). As an example, the University of North Carolina (UNC) system, which consists of 17 institutions, implemented a widespread background check policy for all prospective students after two students were killed in separate incidents on the UNC-Wilmington campus by students who did not disclose their criminal records during the admissions process (Dickerson, 2008).

Institutions of higher education (IHE) have taken this step further by implementing policies on background checks specifically for student-athletes. Through the vetting process, IHE attempt to mitigate future instances of sexual violence on campus by not admitting student-athletes who have committed criminal offenses or serious misconduct in the past. While understanding past indiscretions of recruited athletes are important and vital to campus safety, does the role of "student-athlete" merit the primary focus over others (e.g., fraternities, general student population, etc.)? The founder of the National Coalition Against Violent Athletes has openly questioned the merit of background check policies, stating, "You're talking about less than a fraction of a percentage point of any population," bringing additional questions surrounding this approach (Brown, 2017, para. 28). Therefore, the purpose of this study was to investigate current IHE practices of conducting background checks on student-athletes and to present risk management recommendations to address sexual violence prevention on college campuses.

\section{Institutional Liability in Cases of Campus Sexual Violence}

Due to federal law and the evolution of case law in the area of sex discrimination in education, IHE may be held liable in cases where a student commits an act of sexual violence against another student. As an extension of the 1964 Civil Rights Act, Title IX was enacted in 1972 as protection against discrimination based on sex in educational institutions. The substance of Title IX is brief and ambiguous: "[n]o person in the United States shall, on the basis of sex, be excluded from 
participation in, be denied the benefits of, or be subjected to discrimination under any education program or activity receiving federal financial assistance" (Title IX, 1972, para. 1). The plain language of Title IX did not contain much guidance or restrictions. Thus, the law has been applied to a number of different circumstances related to education and athletics since its inception.

Over time, case law helped clarify the statute and its application to sex-based discrimination in education. Cannon v. University of Chicago (1979) was one of the first major cases applying Title IX, providing the injured with the private right to file suit against an educational institution discriminating based on gender. Franklin v. Gwinnett County Public Schools (1992) extended the application of Title IX by permitting the litigant to seek monetary damages. In Gebser $v$. Lago Vista Independent School District (1998), the United States Supreme Court determined plaintiffs must show notice and the institutions' deliberate indifference in their sexual harassment case, thereby establishing a standard by which an educational institution could be held liable for sexual harassment (Lave, 2016; Parent, 2003). It should be noted that this standard applies in situations where the plaintiff is seeking monetary damages and does not apply to investigations done by the Department of Education (Moorman \& Osbourne, 2016). In Davis v. Monroe County Board of Education (1999), the Supreme Court extended Title IX by applying the law to student-on-student sexual harassment and holding the educational institution potentially liable (Lave, 2016).

In addition, OCR, charged with the execution of Title IX, has disseminated a number of clarification letters providing additional guidance and interpretation of the statute as case law evolved, including addressing sexual violence on college campuses and institutional liability. The OCR clarified the Davis and Gebser cases for educational programs in its 2001 Dear Colleague Letter but failed to provide much direction for colleges to manage instances of sexual assault and sexual violence (Moorman \& Osbourne, 2016). OCR did not issue any guidance on sexual violence on college campuses until its 2011 Dear Colleague Letter. The 2011 letter provided an overview of IHE responsibilities under Title IX, the liability standard, how to meet minimum standards, and guidance on prevention (Moorman \& Osbourne, 2016). According to OCR (2011), preventive measures should be implemented that focus on comprehensive educational measures and training programs. Three years later, OCR published another letter to address various questions raised from the 2011 letter concentrating on institutional responsibilities related to issues of sexual violence on campus (Moorman \& Osbourne, 2016). Although the OCR sought to create standards and norms for IHE to follow under President Barack Obama in 2011, President Donald Trump's Administration rescinded the guidance in 2017, causing confusion and uncertainty regarding how Title IX should be used for campus sexual assault (OCR, 2017). Ultimately, IHE can be held liable for sexually violent offenses under Title IX, as demonstrated in the evolution of case law and federal guidance. Given the potential for liability, in addition to promoting a safe learning environment, IHE are held accountable for mitigating instances of sexual violence on campus. One way to address this issue is to consider how student-athletes play a role in sexually violent crimes on campus. 


\section{Sexual Violence and Intercollegiate Student-Athletes}

Research attempting to correlate athletic participation with the propensity to be sexually violent is both vast and inconsistent. Many studies suggest a connection exists between athletic participation and sexual violence (Boeringer, 1996, 1999; Forbes et al., 2006; Frintner \& Rubinson, 1993; Koss \& Gaines, 1993; McCray, 2015; McMahon, 2011; Murnen \& Kohlman, 2007; Young et al., 2017) while another body of scholarship has found no such connection exists (Caron et al., 1997; Crosset, Benedict, \& McDonald, 1995; Gidycz, Warkentin, \& Orchowski, 2007; Smith \& Stewart, 2003). Moreover, researchers have questioned the findings and assertions between athletic participation and sexual violence due to methodological concerns (Crosset, 1999; Kimble, Russo, Bergman, \& Galindo, 2010; Koss \& Gaines, 1993). Some studies have yielded inconclusive results. For example, Crosset et al. (1995) found that although student-athletes were overrepresented in sexual assault reports, differences between them and non-athletes only existed with the number of incidents reported to judicial affairs. Koss and Gaines (1993) was one of the first empirical studies to utilize athletic participation as a predictor of sexually aggressive behavior, though this association was later found to be weak (Crosset et al., 1995).

Researchers have suggested a number of reasons why student-athletes may be more prone to committing acts of sexual violence. Characteristics associated with one's athletic abilities such as socialization (Crosset, 1999), head injuries (Crowell \& Burgess, 1996), peer and institutional support (Crosset, 1999, 2016), a normativity of interpersonal violence, and lack of team discipline (Crosset, 2016) may contribute to a male athlete's inclination to commit violence against women. Researchers have also suggested alcohol and drug use (Abbey et al., 2002; Koss \& Gaines, 1993; Koss, Gidycz, \& Wisniewski, 1987; Sweeney, 1999), hyper masculinity (Anderson, 2009; Parent, 2003), entitlement related to their position as athletes (Koss \& Gaines, 1993), competitiveness (Caron et al., 1997), and group mentality (Crosset et al., 1995) are also characteristics related to athletic participation and the propensity to commit sexual violence. These characteristics may contribute to an athlete's predisposition to commit an act of sexual violence.

Findings by Caron et al. (1997) suggested athletic characteristics (e.g., competitiveness, win-oriented, etc.) rather than athletic participation may link athletes to sexual violent behavior. Additionally, these behaviors may not be unique to athletes. Research has shown members of fraternities may also have a propensity to commit sexually violent crimes. The homogenous nature of fraternities, the maintenance of secrecy within these groups, and the prevalence of alcohol and drug use have been found to contribute to the "rape prone culture" (Martin, 2016, p. 33) in fraternities (Decker \& Baroni, 2011; Harkins \& Dixon, 2010). Moreover, a study conducted by United Educators (2015) "suggests a subculture within some fraternities and [athletic] teams that promotes hyper-masculinity, sexual aggression and excessive alcohol consumption ... may encourage students within these groups to engage in or excuse sexual violence" (p. 3), highlighting the factors that contribute to committing acts of sexual violence are not unique to athletes. These inconsistent results connecting sexual violence and athletic participation as well as suggestions by Caron et al. (1997) call into question the merit of focusing on mitigating campus sexual assault through policies aimed at student-athletes only. 


\section{Background Checks}

One approach to reducing instances of sexual violence on campuses is the implementation of background checks. Researchers have suggested students who were involved with criminal activity prior to entering college are more likely to engage in criminal misconduct while in college (Runyan, Pierce, Shankar, \& Bangdiwala, 2013). Further, a history of criminal behavior and violence can be considered one of the best predictors for future behavior (Monahan, 2006). Background checks allow officials to become aware of any documented history of criminal or sexual violence an applicant may have.

A key issue when addressing campus safety is whether background checks mitigate issues and improve campus safety (Dickerson, 2010, as cited by Custer, 2016). A primary focus with instilling a policy such as this is campus safety and reducing violence (Pierce, Runyan, \& Bangdiwala, 2014). Background checks have become a widely accepted practice during the admissions process where as many as $35 \%$ of IHE have denied admission to at least one prospective student due to their criminal history (Pierce et al., 2014), highlighting the value of this risk management strategy. In addition, specific academic and vocational programs such as nursing and education, where students may be working with sensitive populations, have required student background checks for some time (Dickerson, 2008).

Information regarding a prospective student's background may be presented in various ways by the student. IHE may require prospective students to submit to a full criminal background check completed by a third-party company. The third-party approach includes a wide search of state databases and usually incurs costs of around $\$ 50$ to $\$ 60$ per student (Stavenhagen, 2017). IHE can choose to absorb the costs or charge it to the prospective student. This screening may also include sex offender databases, credit checks, social media scans, and county-level courthouse searches, though this approach is far from failproof as it may miss some databases or prior issues that may have not led to conviction (Stavenhagen, 2017).

A potentially less invasive route is for prospective students to self-disclose any prior convictions or academic misconduct issues in their admissions application. The self-disclosure approach requests prospective students to state whether they have prior felonies, criminal, or academic misconduct. If a student answers in the affirmative, the institution may request further details and/or additional documentation about the instance (Dickerson, 2008). This approach is flawed due to its reliance on the applicant to provide the information. While schools may collect information regarding students' criminal history, either through a third-party company or through self-disclosure, less than half of IHE have established written policies addressing the information and only $40 \%$ of staff are trained to interpret the information provided (Weissman, Rosenthal, Warth, Wolf, \& Messina-Yauchzy, 2010). The lack of policies and training highlights the potential ineffectiveness of such an approach, especially when overseeing self-disclosure statements (e.g., potential subjectivity surrounding the acceptance of certain previous crimes or misconduct). The competency of admissions staff to navigate such issues is in question (Dickerson, 2008), potentially exposing IHE to liability. 
While background checks may appear to be an efficient way to minimize on-campus violence, institutional liability may exist for institutions that conduct some form of background checks. Prospective students who are denied admission because of a background check may file suit against the institution denying acceptance (Dickerson, 2008). For example, a student who failed to disclose his criminal history on his application for law school at the University of Wisconsin filed a lawsuit against the institution for rescinding his admission after it was made aware of the issue (Martin v. Helstad, 1983). However, courts have upheld the rights of IHE to revoke and deny admission based on a prospective student's criminal record (e.g., Gagne v. Trustees of Indiana, 1998; Burgos v. University of Central Florida Board of Trustees, 2003; Dickerson, 2008). Similarly, a student injured by another student who was knowingly admitted despite having a criminal background may also file suit against the institution. This occurred in Eiseman v. New York (1987), where a convicted felon was admitted to the State University College in Buffalo through a state-funded program for disadvantaged adults. The student murdered two students, raped one, and severely injured another. The estate of the deceased and the survivor brought a lawsuit against the institution for negligence in admitting a known convicted felon.

Another issue with the implementation of background checks in the admissions process is the inconsistency of state laws and public records access, specifically in terms of juvenile records (Potrafke, 2006). State laws dictate the availability of juvenile records and often authorize previous offenders to respond in the negative when asked about their criminal history due to their records being sealed or expunged (Dickerson, 2008). Even so, universities continue to require prospective students to report their criminal history (Dickerson, 2008). For example, the State University of New York system maintains a supplemental application process for prospective students convicted of felonies, which circumvents the state law on public records access by requesting documentation from the student during the admission process (Lantigua-Williams, 2016). Further complicating the inconsistencies of utilizing background checks is the low reporting rates of sexual violence, compounded by even lower conviction rates. According to Lonsway and Archambault (2012), between $7 \%$ and $27 \%$ of sexual assaults reported to police lead to prosecution with approximately $3 \%$ to $26 \%$ of those charges resulting in a conviction that may appear on a criminal background check.

Another significant concern with conducting background checks as a measure of acceptance to IHE is the implication for minority students. Some critics argue policies such as background checks have a disparate impact on minority students (Guerino, Harrison, \& Sabol, 2011; Pierce \& Runyan, 2010). African-Americans are incarcerated at a rate five times higher than Caucasian individuals (Nellis, 2016); therefore, they have a higher chance of disclosing a criminal conviction when applying for admission into IHE. According to Brame, Bushway, Paternoster, and Turner (2014), almost 50\% of African-American men are arrested at least once before the age of 23. Moreover, more African-American men have served prison time than who have earned college degrees (Western, Schiraldi, \& Ziendenberg, 2003); the foregoing information highlights the racial disparity in the criminal justice system. According to the 2018 College Sport Racial \& Gender Report Card, African-American males made up 22.6\% of 
NCAA Division I student-athletes during the 2017-18 academic year (Lapchick, 2018). Considering the alarming statistics on the arrest and incarceration rates for African-Americans, advocates for banning background checks often invoke this argument as a key reason to remove the question from the admissions process (Lantigua-Williams, 2016; U.S. Department of Education, 2016).

The theory behind conducting background checks during the admissions process for IHE may seem like a reasonable and effective policy approach. However, in practice, requiring background checks has its issues. In addition to the aforementioned concerns, research suggests a small percentage of students who reported a previous conviction go on to commit additional crimes during college (Runyan et al., 2013). After the UNC system implemented third-party background checks, it found that over a three-year period and 250,000 admitted students, only 21 students who committed a crime on campus had a criminal history (The University of North Carolina Office of the President, 2004). Runyan et al. (2013) also found that only 3.3\% of graduating seniors who engaged in criminal misconduct during college reported having a conviction on their application. Despite the issues surrounding background checks in admissions, IHE continue the practice and have begun to implement it for student-athletes specifically. Therefore, the purpose of this study was to investigate the current IHE practices of conducting background checks on student-athletes and to present risk management recommendations to address sexual violence prevention on college campuses.

\section{Method}

In order to assess the prevalence of background check policies directed at student-athletes, a systematic approach to data collection was utilized. First, the researchers submitted requests to all NCAA Division I public institutions through the Freedom of Information Act (FOIA). FOIA "has provided the public the right to request access to records from any federal agency" ("What is FOIA?" n.d., para. 1). Private universities are not required to abide by FOIA; therefore, they were omitted from the study. Each NCAA Division I university received a FOIA request in the fall of 2017 asking for any and all university policy statements regarding criminal background checks for prospective students, including student-athletes on athletic scholarships. The FOIA request also asked each institution to provide a copy of the policy and documents students must complete if there is a background check in place. The researchers accepted responses until May 2018, collecting data over a seven-month span. Once the policy documents were received, the researchers reviewed and coded each document. Each policy was coded as the following: (a) the existence of a background check policy for general student admissions; (b) the existence of a background check policy specifically addressing student-athletes; and (c) whether or not the policy included self-disclosure or third-party background checks. The researchers also supplemented the FOIA requests with an Internet search of news articles discussing background check policies, athletic conferences, and intercollegiate athletic departments. Lastly, the researchers reviewed state laws for mandated background checks for student-athletes at the university level. 


\section{Findings}

A review of FOIA responses, media reports, conference policies, and legislative action has provided a picture of the use of background checks in IHE. Ultimately, 41 , or $11.6 \%$ of NCAA Division I, IHE maintain some form of background check for student-athletes specifically. Most are mandated either by its athletic conference policy or state administrative policy. A previous study determined 12 of 567 IHE conducted some form of background checks on student-athletes (Hughes, Elliott, Myers, Heard, \& Nolan, 2016).

A total of 237 NCAA Division I schools were contacted with FOIA requests. There were 352 NCAA Division I IHE at the time of the data collection, with 115 omitted due to their status as a private school. Ninety-seven IHE responded to the FOIA request. Some states such as Tennessee, Arkansas, and Virginia were not obligated to address the FOIA request based on state law, which only require them to respond to citizens of the respective states. A total of 25 public NCAA Division I IHE in the aforementioned states were excluded from the FOIA responses due to state law. Ultimately, 97 IHE responded to the FOIA requests and 140 were non-responsive after multiple attempts. Twenty of the IHE affirmed the existence of some type of background check policy for its student body, either through self-disclosure or a third party. Sixty-two IHE in the FOIA responses stated they had no such policy for the general student population or specifically addressing student-athletes. Of the 20 IHE who have background check policies, only two reported having policies specifically addressing student-athletes. Those universities - the University of Idaho and Texas A\&M University-referred to policies established at the state level or athletic conference, respectively. Both institutions' policies request student-athletes self-disclose any prior misconduct. Refer to Table 1 for a list of all IHE that have background check policies for student-athletes and non-athletes.

The Internet search of news reports and policy statements yielded significant results. The Chronicle of Higher Education reported the Big 12 Conference, the Southeastern Conference (SEC), and the Pacific-12 Conference (Pac-12) maintain some form of policy restricting the recruitment of players with a record of sexual assault or domestic violence (Brown, 2017). The SEC was one of the first conferences to implement a serious misconduct policy in 2015 for transfer student-athletes but updated its policy in 2018 to include incoming freshmen (Crepea, 2018). The Big 12 policy only includes transfer student-athletes (Brown, 2017). The Pac-12 also maintains a policy restricting the acceptance of transfer student-athletes with past misconduct issues.

Prior to the Big 12 Conference approval of the background checks policy, Tulsa World reported Texas Christian University, a private university, conducted background checks through a third-party firm on all prospective student-athletes (Stavenhagen, 2017). Big 12 member University of Oklahoma (OU) has conducted criminal background checks on all prospective student-athletes since 2005 (Timanus, 2005). OU's policy requires potential recruits to participate in a background check before they receive an official letter of intent from the university (Timanus, 2005). OU's policy also required a third-party company to conduct the background checks (Stavenhagen, 2017). In addition, other members of the Big 12 (e.g., Baylor University, the University of Kansas [UK], and Kansas 
State University [KSU]) have implemented background checks for transfer student-athletes as early as 2005 (Marklein, 2007). UK conducts background checks through a third-party company for all transfer athletes. KSU performs an online search of incoming athletes and will follow up with an official background check through a third-party company if an issue arises (Stavenhagen, 2017).

Some universities within the Pac-12 specifically extended the conference policy, which only addresses transfer students, to include freshmen. For example, the University of Utah does not allow for the recruitment of known felons out of high school (Grief, 2017). Similar to much of the findings, The Oregonian found that all prospective students who apply to the University of Oregon are required to disclose past convictions. From there, the athletic department has the capability to clear or disqualify athletes on a case-by-case basis (Grief, 2017).

There is also legislative action in the area of student-athlete recruitment. The Idaho Department of Education adopted a statewide policy prohibiting any Idaho public university from recruiting athletes with a felony conviction as an adult or juvenile (Potrafke, 2006). This policy directly affects University of Idaho, Boise State University, and Idaho State University. Virginia state law requires all associate and baccalaureate public and private IHE to submit information for all prospective students to the Department of State Police to cross-reference information in the Virginia Criminal Information Network and the National Crime Information Center Sex Offender Registry File (Va. Code § 23.1-407, 2006). This law affects 14 Division I institutions across the state of Virginia. Finally, as previously noted, the UNC system requires all prospective students to complete a background check through a third-party company. This includes 17 Division I institutions across the state.

A number of individual IHE have taken the steps to implement policies without conference or legislative mandate. Approved in 2017, Indiana University's policy specifically addresses sexual violence and student-athletes and requires criminal background checks on all prospective athletes in addition to an Internet search and interviews with their teammates, family members, and coaches (Dodd, 2017; Indiana University, 2017). Fresno State University's policy dates back to 2001 and states coaches cannot recruit or sign an athlete with a felony or misdemeanor charge or has previously violated any NCAA regulations (California State University Fresno, 2001). Additionally, despite not having formal policies, some IHE (e.g., Iowa State University, The Ohio State University, and Texas Tech University) ask their coaches to vet prospective student-athletes through former coaches and close acquaintances (Stavenhagen, 2017).

\section{Discussion and Implications}

The implementation of background check policies has evolved due to issues of campus safety and reducing violence (Pierce et al., 2014). IHE have begun targeting student-athletes as the source of campus violence, primarily surrounding sexual assaults. There have been studies that suggest a connection exists between athletic participation and committing acts of sexual violence (Boeringer, 1996, 1999; Forbes et al., 2006; Frintner \& Rubinson, 1993; Koss \& Gaines, 1993; McCray, 2015; McMahon, 2011; Murnen \& Kohlman, 2007; Young et al., 2017). Both research and media reports of sexually violent crimes 
Table 1.

\begin{tabular}{|c|c|c|}
\hline \multicolumn{3}{|r|}{ Results } \\
\hline Policy & $\begin{array}{l}\text { Number } \\
\text { of IHE }\end{array}$ & IHE \\
\hline $\begin{array}{l}\text { IHE with some form of } \\
\text { background check for all } \\
\text { prospective students }\end{array}$ & 20 & $\begin{array}{l}\text { Florida Gulf Coast University, University of North Florida, University of } \\
\text { Florida, University of Idaho, Sam Houston State University, University } \\
\text { of Georgia, Georgia Southern University, Georgia State University, } \\
\text { Illinois State University, Southern Illinois University - Edwardsville, } \\
\text { Ball State University, Western Michigan University, University of South } \\
\text { Carolina - Columbia, College of Charleston (South Carolina), Clemson } \\
\text { University, Purdue University, Michigan State University, Florida } \\
\text { Atlantic University, University of Wyoming, Miami University (Ohio) }\end{array}$ \\
\hline $\begin{array}{l}\text { IHE with some form of } \\
\text { background check for all } \\
\text { student-athletes }\end{array}$ & 38 & $\begin{array}{l}\text { Indiana University; Fresno State University; Big-12 Conference (i.e., } \\
\text { Baylor University, lowa State University, University of Kansas, Kansas } \\
\text { State University, University of Oklahoma, Oklahoma State University, } \\
\text { Texas Christian University, University of Texas-Austin, Texas Tech } \\
\text { University, and the University of West Virginia); } \\
\text { SEC (i.e., University of Alabama, University of Arkansas, Auburn } \\
\text { University, University of Florida, University of Georgia, University } \\
\text { of Kentucky, Louisiana State University, University of Mississippi, } \\
\text { Mississippi State University, University of Missouri, University of } \\
\text { South Carolina, University of Tennessee, Texas A\&M University, and } \\
\text { Vanderbilt University); } \\
\text { Pac-12 (i.e., University of Arizona, Arizona State University, University } \\
\text { of California - Berkeley, University of California - Los Angeles, } \\
\text { University of Colorado, University of Oregon, Oregon State University, } \\
\text { University of Southern California, Stanford University, University of } \\
\text { Utah, University of Washington, and the Washington State University) }\end{array}$ \\
\hline $\begin{array}{l}\text { IHE required by } \\
\text { state-mandated policy } \\
\text { to complete background } \\
\text { checks on all prospective } \\
\text { students }\end{array}$ & 31 & $\begin{array}{l}\text { North Carolina: Appalachian State University, Campbell University, } \\
\text { Davidson College, Duke University, East Carolina University, Gardner- } \\
\text { Webb University, High Point University, University of North Carolina } \\
\text { Asheville, North Carolina A\&T State University, North Carolina Central } \\
\text { University, North Carolina State University, University of North Carolina } \\
\text { Wilmington, University of North Carolina, Chapel Hill, The University } \\
\text { of North Carolina at Charlotte, The University of North Carolina at } \\
\text { Greensboro, Wake Forest University, Western Carolina University } \\
\\
\text { Virginia: George Mason University, Hampton University, James } \\
\text { Madison University, Liberty University, Longwood University, Norfolk } \\
\text { State University, Old Dominion University, Radford University, } \\
\text { University of Richmond, University of Virginia, Virginia Commonwealth } \\
\text { University, Virginia Military Institute, Virginia Polytechnic Institute and } \\
\text { State University, College of William \& Mary }\end{array}$ \\
\hline $\begin{array}{l}\text { IHE required by } \\
\text { state-mandated } \\
\text { policy to complete } \\
\text { background checks on } \\
\text { student-athletes }\end{array}$ & 3 & $\begin{array}{l}\text { Idaho: Boise State University, University of Idaho, Idaho State } \\
\text { University }\end{array}$ \\
\hline
\end{tabular}


committed by student-athletes have provided IHE with enough data to focus on this population in order to promote campus safety. The findings in the current study suggest the implementation of background checks for student-athletes has become a more widely accepted practice despite its issues including lack of policies to address information yielded from background checks (Weissman et al., 2010), inconsistency of access to public juvenile records across states (Potrafke, 2006), and disparate impact (Guerino et al., 2011; Pierce \& Runyan, 2010). These issues may potentially expose IHE to institutional liability.

IHE may also face institutional liability surrounding policy implementation and execution. While the current study did not include a systematic content analysis of the policies, there were some notable points. First, IHE may open themselves up to liability due to membership in specific athletic conferences, as they are the source of such policies. Conference policies guided many of the universities but appear to lack in procedural elements. The Pac-12's policy requires prospective transfer students to self-disclose any instances of "student behavior or academic misconduct" within the previous seven years, which could include "assault, harassment, academic fraud and other violations of campus behavior conduct policies" (Pac-12 Conference, 2016, p. 32). Comparatively, SEC member institutions are expected to execute "due diligence in reviewing a prospective athlete's background" (Crepea, 2018, para. 3). The SEC provides a document within its bylaws that offers guidance for the minimum expectations for due diligence inquiries, including a list of questions to ask recruits (Southeastern Conference, 2017). Finally, Big 12 members must "exercise diligence to identify and address ... serious misconduct issues involving its prospective student-athletes" (Big 12 Conference, 2017, p. 36), leaving this policy open to broad interpretation and with no substantive or procedural guidance. There is a great degree of variation in policy implementation and execution.

In general, the athletic conference policies lack procedure and substantive elements that could guide member institutions to make legally sound decisions (Dickerson, 2008). This situation may potentially expose the member institution and the athletic conference to additional liability, as previous research has found that only $40 \%$ of staff are trained to interpret the information provided by students (Weissman et al., 2010), prompting opportunities for mistakes to occur. Further, if the NCAA were to implement a similar policy to unify all Division I IHE, as some researchers have suggested (e.g., Potrafke, 2006), such a decision may invite legal liability in tort or via constitutional challenge for those schools who are state actors. The NCAA's decision to end the CCSV without mandating some form of background check may speak to the Association's hesitancy to pursue such an option. This decision may be well-founded, as background checks lack effectiveness when it comes to preventing criminal activity (e.g., Stavenhagen, 2017), and data does not conclusively illustrate that student-athletes are more likely to perpetrate criminal acts or sexually violent crimes than others. In light of this discovery, a more nuanced approach to campus safety may be recommended over an NCAA edict requiring background checks.

Secondly, there are also issues with background checks through third-party companies. For example, OU, which has conducted full third-party background checks since 2005, admitted an athlete who had two domestic violence allegations 
unbeknownst to the institution (Stavenhagen, 2017). Third-party background checks are not perfect since they have to navigate numerous databases. It should be noted that OU subsequently switched its vendor and expanded the reach of the background checks (Stavenhagen, 2017). In addition, despite many IHE having blanket background check policies for all prospective students, some IHE provide athletic departments with the freedom to clear athletes on a case-by-case basis. This situation could further create institutional liability if a student-athlete with a past conviction is cleared and commits a criminal act while enrolled at the institution.

Lastly, the limited access to juvenile records, depending on the state, makes this approach erratic. Due to the inconsistency across states in terms of access to juvenile records, some athletic departments have bypassed conducting background checks on incoming freshmen. For example, Big 12 member Baylor University, a private university located in Texas, has had a background check policy strictly for transfer students since 2005. Texas statutes limit access to juvenile records, which is the population from which a majority of Baylor recruiting is conducted (Datz, 2005).

\section{Recommendations}

Campus sexual assault and violence needs to be addressed proactively. While IHE may opt to implement background checks for student-athletes, this approach is not fail-proof. Although research and media reports point to student-athletes as the primary culprits of sexual violence on campus, the approach to campus safety should include all students as well as student-athletes. Background checks may seem like a suitable approach, but also could provide a false sense of security for administrators, students, and the campus community. Further, the existence of a background checks policy should not stand as a replacement for other forms of prevention. Fortunately, there are a number of other approaches to reducing sexual violence on campus, such as promoting sexual violence awareness, prevention education, and bystander intervention programming for student-athletes and the general student population.

As previously discussed, in 2017 the NCAA membership adopted a sexual violence policy proposed by the CCSV. This policy requires NCAA coaches, student-athletes, and athletic administrators to complete sexual violence prevention education every year, with university administration verifying the completion of the training (NCAA, 2017). This suggestion is an initial step to address campus sexual violence, but more could be done. Unfortunately, the CCSV was disbanded before it could make significant strides (Wyden et al., 2019). The NCAA and athletic conferences should continue to develop and evaluate programming for its student-athletes. Additionally, athletic departments can build upon this policy with Athlete Codes of Conduct and promote the development of safety advocate groups within the student-athlete population.

In addition to sexual violence prevention education, other relevant programming should be offered to both student-athletes and the general student population. For example, the University of Kentucky offers a bystander intervention training that educates students on strategies for intervening in potentially dangerous situations (Zimmerman, 2016). The program, adopted by some Kentucky high schools, indicated a $50 \%$ decrease in the frequency of student-related sexual 
assaults after five years (Zimmerman, 2016). Other preventative programs have been implemented such as the Zero Tolerance Approach, a 10-hour program that covers a wide array of topics such as bystander intervention, healthy sex education, and a discussion to define sexual assault, consent, and rape culture in sports (McCray, McDougal, \& McNeil, 2018). According to the CDC, effective sexual assault prevention requires programs and policies that address individual, relationship, community, and societal factors (Basile et al., 2016). The CDC offers a variety of evidence-based programs and an online tool kit that can be adopted and implemented by IHE.

If IHE choose to retain the background check policy during the admissions process for either prospective or transfer student-athletes, they must develop sound policies and procedures when addressing individual student circumstances, ensuring the process does not allow for arbitrary or capricious selection (Dickerson, 2008). For example, there are a number of athletic programs that conduct background checks via Internet searches and interviews with known associates, which potentially can lead to selection bias. The Center for Community Alternatives suggested if IHE retain the background check approach, the following steps should be followed:

1) Remove self-disclosure requirement from initial application for admission

2) Limit disclosure requirement to specific types of convictions

3) Establish admissions criteria that are fair and evidence-based

4) Base admissions decisions on assessments that are well-informed and unbiased

5) Establish procedures that are transparent and consistent with due process

6) Offer support and advocacy

7) Evaluate the policy periodically to determine whether it is justified (Weissman et al., 2010, pp. 33-40)

An important aspect of this process is training those involved with the recruiting and admissions process to effectively interpret, understand, and act upon data as well as manage such a responsibility (Weissman et al., 2010).

It is beyond the scope of this study to recommend whether IHE should or should not accept students with a criminal past. The purpose of this study was to investigate IHE current practices of conducting background checks on student-athletes and to present risk management recommendations to address sexual violence prevention on college campuses. These recommendations would help provide IHE with enough information to make an informed decision on their approach to mitigating campus sexual violence. Ultimately, if an institution decides to accept an athlete with a sexual violent and/or criminal background, it is exposing itself to potential institutional liability. Moreover, there are varying levels of sexual violence, and based on state and federal laws, each may yield a different punishment (pursuant to its classification as a misdemeanor or felony). Ultimately, the decision lies with the institution on whether it would accept a student or student-athlete with such a background, if this information 
is available for public consumption, considering state laws regarding juvenile records. It is our recommendation that IHE create and enforce uniform policies and procedures for student and student-athlete recruitment and acceptance, promote sexual violence awareness, and conduct prevention education and bystander intervention programming for its students and student-athletes once they become a part of the institution. Additionally, IHE should continuously evaluate the policies' effectiveness, educate and train admissions staff how to interpret and address background check results and university policy, and regularly update programming to evolve as IHE expectations progress.

\section{Conclusion}

This study sought to learn more about how universities may use background checks to reduce sexual violence among students. Campus safety is a priority for colleges and universities. The challenge to avoid student-athletes with past misconduct remains an issue for athletic departments. SEC commissioner Greg Sankey has acknowledged the challenge schools face with researching prospective student-athletes (Crepea, 2018). The implementation of background checks for students and student-athletes has been implemented on college campuses as a way to minimize crime on campus. More recently, this vetting process has been utilized to reduce the instances of sexual violence involving student-athletes as the perpetrators. Research surrounding student-athletes' relationship with committing acts of sexual violence is inconsistent, but calls for more action remain. Students, advocacy groups, lawmakers, and the media demand the NCAA and the "Power 5" conferences to do more to stop campus sexual violence.

While background checks may be one way to approach campus safety, and have become more popular among IHE, it should be combined with other elements and strategies such as prevention education, bystander training, counseling, and policing (Dickerson, 2008). Background checks may be a tool to reduce the instance of crime on campus, but it should not be the only approach. Further, background checks may increase institutional liability due to inconsistent policies and procedures (Dickerson, 2008; Levine, Cintron, \& McCray, 2019; Weissman et al., 2010). Background checks can be ineffective due to low recidivism rates (Guerino et al., 2011; Pierce \& Runyan, 2010) and lack of access to juvenile records (Potrafke, 2006). If IHE retain the background check approach, the development of consistent and fair policies and procedures are necessary. A more holistic approach includes the creation and enforcement of uniform policies and procedures for student and student-athlete recruitment and acceptance, proper education and training for those administrators charged with interpreting information provided in background checks, the promotion and education of issues surrounding sexual violence, and the implementation of prevention education and bystander intervention programming for students and student-athletes once they become a part of the institution.

This study does not come without its limitations. Primarily, the researchers focused on NCAA Division I public institutions, which make up a small proportion of all college athletic programs. Private institutions were not contacted for data collection for this study. Additionally, the current study relied on IHE to 
self-report their policies on background checks, which may have been left open to interpretation. Further, numerous IHE failed to respond to the researcher's request for information.

Future research in this area can expand with an in-depth legal analysis of the content of background check policies adopted by athletic conferences. Additionally, researchers can expand on the legal implications of background check polices in student-athlete recruitment. Future research should include more considerations on preventing sexual harassment; though not misdemeanor or felony behavior, it is harmful enough to be included in Title IX guidance. Even in the face of changing Title IX regulations between presidential administrations, it is still considered harmful enough to be regulated and punished (Title IX, 1972). Further, in light of the recent allegations by Ohio State University athletes of sexual abuse by a university team doctor (Edmondson, 2018), same-sex sexual violence should be also studied to shed more light on potential prevention strategies. Lastly, as USA Gymnastics continues to deal with the consequences of Larry Nassar's actions (Armour, Axon, \& Evans, 2018), institutional response and prevention at the youth sport and Olympic levels need further consideration.

\section{References}

Abbey, A., Zawacki, T., Buck, P. O., Testa, M., Parpks, K., Norris, J., ... Martell, J. (2002). How does alcohol contribute to sexual assault? Explanations from laboratory and survey data. Alcoholism: Clinical and Experimental Research, 26, 575-581. https://doi. org/10.1111/j.1530-0277.2002.tb02576.x

Anderson, E. D. (2009). The maintenance of masculinity among the stakeholders of sport. Sport Management Review, 12, 3-14. https://doi.org/10.1016/j.smr.2008.09.003

Armour, N., Axon, R., \& Evans, T. (2018, December 5). USA Gymnastics files for bankruptcy, a move related to Larry Nassar's sexual abuse lawsuits. USA Today. Retrieved from https://www. usatoday.com/story/sports/olympics/2018/12/05/usa-gymnastics-files-bankruptcy-nassar-lawsuits/2218546002/

Baker, K. K. (2016). Campus sexual misconduct as sexual harassment: A defense of the DOE. Kansas Law Review, 64, 861-889.

Basile, K. C., Smith, S. G., Brieding, M. J., Black, M. C., \& Mahendra, R. R. (2014). Sexual violence surveillance: Uniform definitions and recommended data elements. Atlanta, GA: National Center for Injury Prevention and Control, Centers for Disease Control and Prevention.

Basile, K. C., DeGue, S., Jones, K., Freire, K., Dills, J., Smith, S. G., \& Raiford, J. L. (2016). STOP SV: A technical package to prevent sexual violence. Atlanta, GA: National Center for Injury Prevention and Control, Centers for Disease Control and Prevention.

Beaver, W. R. (2017). Campus sexual assault: What we know and what we don't. The Independent Review, 22, 257-268.

Big 12 Conference. (2017). 2017-18 Conference handbook. Irving, TX: Author. Retrieved from http://www.big12sports.com/fls/10410/pdfs/handbook/ConferenceHandbook.pdf?DB_OEM_ $\underline{\mathrm{ID}=10410}$

Black, M. C., Basile, K. C., Breiding, M. J., Smith, S. G., Walters, M. L., Merrick, M. T., Chen, J., \& Stevens, M. R. (2011). The National Intimate Partner and Sexual Violence Survey (NISVS): 2010 Summary Report. Atlanta, GA: National Center for Injury Prevention and Control, Centers for Disease Control and Prevention. 
Boeringer, S. B. (1996). Influences of fraternity membership, athletics, and male living arrangements on sexual aggression. Violence Against Women, 2, 134-147. https://doi. org $/ 10.1177 / 1077801296002002002$

Boeringer, S. B. (1999). Associations of rape-supportive attitudes with fraternal and athletic participation. Violence Against Women, 5, 81-90. https://doi.org/10.1177/10778019922181167

Brame, R., Bushway, S., Paternoster, R., \& Turner, M. (2014). Demographic patterns of cumulative arrest prevalence by ages 18 and 23. Crime \& Delinquency, 60, 471-486.

Brener, N. D., McMahon, P. M., Warren, C. W., \& Douglas, K. A. (1999). Forced sexual intercourse and associated health-risk behaviors among female college students in the United States. Journal of Consulting and Clinical Psychology, 67, 252-259. https://doi.org/10.1037/0022$\underline{006 X .67 .2 .252}$

Brown, A. (2017, August 9). Big-time sports programs tighten rules on athletes with sexual-assault records. The Chronicle of Higher Education. Retrieved from https://www.chronicle.com/article/ Big-Time-Sports-Programs/240892

Burgos v. University of Central Florida Board of Trustees, 283 F.Supp.2d 1268 (2003).

California State University Fresno. (2001). Student athlete recruitment code. Fresno, CA: Author. Retrieved from http://www.fresnostate.edu/mapp/documents/apm/410.pdf

Cannon v. University of Chicago, 441 U.S. 677 (1979).

Caron, S. L., Halteman, W. A., \& Stacy, C. (1997). Athletes and rape: Is there a connection? Perceptual and Motor Skills, 85, 1379-1393. https://doi.org/10.2466/pms.1997.85.3f.1379

Coakley, J. (2009). Sports in society: Issues and controversies (10th ed.). New York, NY: McGraw-Hill.

Crepea, J. (2018, June 1). SEC expands serious misconduct policy to include high school signees. AL.com. Retrieved from https://www.al.com/sports/index.ssf/2018/06/sec expands serious misconduct.html

Crosset, T. W. (1999). Male athletes' violence against women: A critical assessment of the athletic affiliation, violence against women debate. Quest, 51, 244-257. https://doi.org/10.1080/0033629 7.1999.10491684

Crosset, T. W. (2016). Athletes, sexual assault, and universities' failure to address rape-prone subcultures on campus. In S. C. Wooten \& R. W. Mitchell (Eds.), The crisis of campus sexual violence: Critical perspectives on prevention and response (pp. 74-91). New York, NY: Routledge. https://doi.org/10.4324/9781315725604-5

Crosset, T. W., Benedict, J. R., \& McDonald, M. A. (1995). Male student-athletes reported for sexual assault: A survey of campus police departments and judicial affairs offices. Journal of Sport and Social Issues, 19, 126-140. https://doi.org/10.1177/019372395019002002

Crowell, T., \& Burgess, A. (Eds.) (1996). Understanding violence against women. Washington, DC: National Academy Press. https://doi.org/10.1037/10204-000

Custer, B. (2016). College admission policies for ex-offender students: A literature review. Journal of Correctional Education, 67(2), 35-43.

Datz, T. (2005, July 1). Background checks on campus. CSO Online. Retrieved from https://www. csoonline.com/article/2118206/investigations-forensics/background-checks-on-campus.html

Davis v. Monroe County Board of Education, 526 U.S. 629 (1999).

Decker, J. F., \& Baroni, P. G. (2011). "No" still means "yes": The failure of the "non-consent" reform movement in American rape and sexual assault law. The Journal of Criminal Law and Criminology (1973-), 101, 1081-1169.

Dickerson, D. (2008). Background checks in the university admissions process: An overview of legal and policy considerations. Journal of College and University Law, 34, 419-505. 
Dickerson, D. (2010). Background checks and the university admissions process. Paper presented at the meeting of the National Association of College and University Attorneys, Washington, D.C.

Dodd, D. (2017, April 15). U.S. Senators ask NCAA to develop a 'uniform policy' on sexual assault. CBS Sports. Retrieved from https://www.cbssports.com/college-football/news/u-s-senators-ask-ncaa-to-develop-a-uniform-policy-on-sexual-assault/

Edmondson, C. (2018, July 20). More than 100 former Ohio State students allege sexual misconduct. The New York Times. Retrieved from https://www.nytimes.com/2018/07/20/us/politics/ sexual-misconduct-ohio-state.html

Eiseman v. State of New York, 70 NY2d 175 (1987).

What is FOIA? (n.d.). FOIA.gov. Retrieved from https://www.foia.gov/about.html

Forbes, G., Adams-Curtis, L., Pakalka, A., \& White, K. (2006). Dating aggression, sexual coercion, and aggression-supporting attitudes among college men as a function of participation in aggressive high school sports. Violence Against Women, 12, 441-455.

Franklin v. Gwinnett County Public Schools, 503 U.S. 60 (1992).

Frintner, M. P., \& Rubinson, L. (1993). Acquaintance rape: The influence of alcohol, fraternity membership, and sports team membership. Journal of Sex Education and Therapy, 19, 272-284. https://doi.org/10.1080/01614576.1993.11074089

Gagne v. Trustees of Indiana, 692 N.E.2d 489 (1998).

Gebser v. Lago Vista Independent School District, 524 U.S. 274 (1998).

Giambalvo, E. (2017, July 17). Students ask WSU for policy preventing recruitment of athletes with a history of sexual violence. Seattle Times. Retrieved from https://www.seattletimes.com/ sports/wsu-cougars/students-ask-wsu-for-policy-preventing-recruitment-of-athletes-with-history-of-sexual-violence/

Gibbs, L. (2018, December 21). Michigan State is still trying to cover up its enabling of Larry Nassar. ThinkProgress. Retrieved from https://thinkprogress.org/michigan-state-is-still-tryingto-cover-up-its-enabling-of-larry-nassar-b9628d0ed20c/

Gidycz, C. A., Warkentin, J. B., \& Orchowski, L. M. (2007). Predictors of perpetration of verbal, physical, and sexual violence: A prospective analysis of college men. Psychology of Men \& Masculinity, 8, 79-94. https://doi.org/10.1037/1524-9220.8.2.79

Grief, A. (2017, June 12). Brenda Tracy lobbies NCAA Power 5 schools for tougher stance for athletes with sexual violence records. The Oregonian. Retrieved from http://www.oregonlive. com/ducks/index.ssf/2017/06/brenda_tracy_lobbies_ncaa_powe.html

Guerino, P., Harrison, P. M., \& Sabol, W. J. (2011). Prisoners in 2010 (236096). Washington, DC: Bureau of Justice Statistics, U.S. Department of Justice. Retrieved from http://bjs.ojp.usdoj.gov/ content/pub/pdf/p10.pdf

Harkins, L., \& Dixon, L. (2010). Sexual offending in groups: An evaluation. Aggression and Violent Behavior, 15(2), 87-99. https://doi.org/10.1016/j.avb.2009.08.006

Hughes, S., Elliott, T., Myers, M., Heard, C., \& Nolan, J. (2016). College athletics and background checks: Literature review and survey results. Retrieved from http://riskaware.com/wp-content/ uploads/2015/04/College-Athletics-and-Background-Check-Policies.pdf

Indiana University. (2017, April 12). Indiana University athletics policy disqualifying prospective student-athletes with records of sexual violence. Bloomington, IN: Author. Retrieved from http://iuhoosiers.com/documents/2017/4/19/Indiana_University Athletics Policy Disqualifying Prospective Student Athletes with Records of Sexual Violence $4 \quad 5 \quad 20173$. pdf?id=22782 
Jacoby, K. (2019, December 16). NCAA looks the other way as college athletes punished for sex offenses play on. USA Today. Retrieved from https://www.usatoday.com/in-depth/news/investigations/2019/12/12/ncaa-looks-other-way-athletes-punished-sex-offenses-play/4360460002/

Kimble, N., Russo, S., Bergman, B., \& Galindo, V. (2010). Revealing an empirical understanding of aggression and violent behavior in athletics. Aggression and Violent Behavior, 15, 446-462. https://doi.org/10.1016/j.avb.2010.08.001

Koss, M. P., \& Gaines, J. A. (1993). The prediction of sexual aggression by alcohol use, athletic participation, and fraternity affiliation. Journal of Interpersonal Violence, 8, 94-108. https://doi. org $/ 10.1177 / 088626093008001007$

Koss, M. P., Gidycz, C. A., \& Wisniewski, N. (1987). The scope of rape: Incidence and prevalence of sexual aggression and victimization in a national sample of higher education students. Journal of Consulting and Clinical Psychology, 55, 162-170. https://doi.org/10.1037/0022$\underline{006 X .55 .2 .162}$

Krebs, C. P., Lindquist, C. H., Warner, T. D., Fisher, B. S., \& Martin, S. L. (2007). The Campus Sexual Assault (CSA) Study. (NCJRS Document No. 221153). Retrieved from https://www.ncjrs. gov/pdffiles1/nij/grants/221153.pdf

Ladika, S. (2017, April 28). Sports and sexual assault. CQ Researcher, 27, 361-384.

Lantigua-Williams, J. (2016). 'Ban the box' goes to college. The Atlantic. Retrieved from https:// www.theatlantic.com/politics/archive/2016/04/ban-the-box-comes-to-campus/480195/

Lave, T. R. (2016). A critical look at how top colleges and universities are adjudicating sexual assault. University of Miami Law Review, 71, 376-426.

Lapchick, R. (2018). College sport racial \& gender report card. Orlando, FL: University of Central Florida. Retrieved from https://docs.wixstatic.com/ugd/7d86e5 c8e69a54d92b4c35a94a5e399e7fe167.pdf

Lavigne, P., \& Noren, N. (2018, February 1). OTL: Michigan State secrets extend far beyond Larry Nassar case. ESPN. Retrieved from http://www.espn.com/espn/story//id/22214566/pattern-denial-inaction-information-suppression-michigan-state-goes-larry-nassar-case-espn

Levine, J. F., Cintron, A. M., \& McCray, K. L. (2019). Legal implications of conducting background checks on intercollegiate student athletes. Marquette Sports Law Review, 30(1), 85-115.

Lonsway, K. A., \& Archambault, J. (2012). The "justice gap" for sexual assault cases: Future directions for research and reform. Violence Against Women, 18, 145-168. https://doi. org $/ 10.1177 / 1077801212440017$

Marklein, M. B. (2007, April 18). An idea whose time has come? Schools increasingly subjecting applicants to background checks. USA Today, p. 7D.

Martin, P. Y. (2016). The rape prone culture of academic contexts: Fraternities and athletics. Gender \& Society, 30, 30-43. https://doi.org/10.1177/0891243215612708

Martin v. Helstad, 578 F. Supp. 1473 (W.D. Wis. 1983).

Melnick, M. (1992). Male athletes and sexual assault. Journal of Physical Education, Recreation \& Dance, 63, 32-35. https://doi.org/10.1080/07303084.1992.10604186

McCray, K. L. (2015). Intercollegiate athletes and sexual violence: A review of literature and recommendations for future study. Trauma, Violence, \& Abuse, 16, 438-443. https://doi. org $/ 10.1177 / 1524838014537907$

McCray, K. L., McDougal, K., \& McNeil, C. (2018). A zero tolerance approach: Assessing the effectiveness of sexual assault prevention education for intercollegiate athletes. Paper presented at the meeting of the North American Society for Sport Management, Halifax, Nova Scotia.

McMahon, S. (2011). Rape myth beliefs and bystander attitudes among incoming college students. Journal of American College Health, 59, 3-11. https://doi.org/10.1080/07448481.2010.483715 
Moorman, A. M., \& Osborne, B. (2016). Are institutions of higher education failing to protect students: An analysis of Title IX's sexual violence protections and college athletics. Marquette Sports Law Review, 26, 545-582.

Monahan, J. (2006). A jurisprudence of risk assessment: Forecasting harm among prisoners, predators, and patients. Virginia Law Review, 92, 391-435.

Murnen, S. K., \& Kohlman, M. H. (2007). Athletic participation, fraternity membership, and sexual aggression among college men: A meta-analytic review. Sex Roles, 57, 145-157. https:// doi.org/10.1007/s11199-007-9225-1

National Institute for Justice. (2010). Victims and perpetrators. National Institute of Justice: Office of Justice Programs. Retrieved from http://www.nij.gov/topics/crime/rape-sexual-violence/ Pages/victims-perpetrators.aspx

NCAA. (n.d.). NCAA commission to combat campus sexual violence. Retrieved from http://www. ncaa.org/governance/committees/ncaa-commission-combat-campus-sexual-violence

NCAA. (2017, August 10). Board adopts sexual violence policy. Retrieved from http://www.ncaa. org/about/resources/media-center/news/board-adopts-sexual-violence-policy

Nellis, A. (2016). The color of justice: Racial and ethnic disparity in state prisons. Washington, D.C.: The Sentencing Project. Retrieved from http://www.sentencingproject.org/publications/ color-of-justice-racial-and-ethnic-disparity-in-state-prisons/

Office for Civil Rights. (2001). Revised sexual harassment guidance: Harassment of students by school employees, other students, or third parties. Washington D.C.: U.S. Department of Education. Retrieved from https://www2.ed.gov/about/offices/list/ocr/docs/shguide.html

Office for Civil Rights. (2011, April 4). Dear colleague letter. Retrieved from https://www2. ed.gov/about/offices/list/ocr/letters/colleague-201104.pdf

Office for Civil Rights. (2017, September). Dear colleague letter. Retrieved from https://www2. ed.gov/about/offices/list/ocr/docs/qa-title-ix-201709.pdf

Pac-12 Conference. (2016, March 12). Misconduct issues of transfer student-athletes. Retrieved from http://pac-12.com/article/2016/03/12/pac-12-announces-new-policy-dealing-misconduct-issues-transfer-student-athletes

Parent, C. M. (2003). Personal fouls: How sexual assault by football players is exposing universities to Title IX liability. Fordham Intellectual Property Media \& Entertainment Law Journal, 13, 617-652.

Pierce, M. W., \& Runyan, C. W. (2010). Criminal records and college admissions. Injury Prevention, 16, 58-60. https://doi.org/10.1136/ip.2008.021345

Pierce, M. W., Runyan, C. W., \& Bangdiwala, S. I. (2014). The use of criminal history information in college admissions decisions. Journal of School Violence, 13, 359-376. https://doi.org/10.1080 $\underline{15388220.2013 .870061}$

Potrafke, L. M. (2006). Checking up on student-athletes: A NCAA regulation requiring criminal background checks. Marquette Sports Law Review, 17, 427-450.

Reyes, L. (2018, July 26). Buccaneers' Jameis Winston 'focused on moving forward' from Uber incident, suspension. USA Today. Retrieved from https://www.usatoday.com/story/sports/nfl/ buccaneers/2018/07/26/jameins-winston-suspension-uber-tampa-bay-buccaneers/841340002/

Rittenberg, A. (2019, February 7). U.S. Senators urge Power 5 commissioners to enhance sexual violence policies. ESPN. Retrieved from http://www.espn.com/college-football/story/_/ $\underline{\mathrm{id} / 25947938 / \text { us-senators-urge-power-5-commissioners-enhance-sexual-violence-policies }}$

Runyan, C., Pierce, M., Shankar, V., \& Bangdiwala, S. (2013). Can student-perpetrated college crime be predicted based on precollege misconduct? Injury Prevention, 19, 405-411. https://doi. org/10.1136/injuryprev-2012-040644 
Smith, D., \& Stewart, S. (2003). Sexual aggression and sports participation. Journal of Sport Behavior, 26, 384-395.

Southeastern Conference. (2017). Constitution \& bylaws. Birmingham, AL: Author. Retrieved from http://a.espncdn.com/photo/2018/0217/2017-18\%20SEC $\% 20$ Constitution $\% 20$ and $\% 20$ Bylaws.pdf

Stavenhagen, C. (2017, January 30). Criminal background checks remain a rarity despite issues in college sports. Tulsa World. Retrieved from http://www.tulsaworld.com/sportsextra/collegefootball/criminal-background-checks-remain-a-rarity-despite-issues-in-college/article_09416217$\underline{\text { f22c-560e-8bea-484ba787ca84.html }}$

Sweeney, T. N. (1999). Closing the campus gates-Keeping criminals away from the university-The story of student-athlete violence and avoiding institutional liability for the good of all. Seton Hall Journal of Sport Law, 9, 226-262.

The University of North Carolina Office of the President. (2004, December 14). Task force on the safety of the campus community. Chapel Hill, NC: Author. Retrieved from http://counsel.cua. edu/res/docs/final-safety-task-force-report.pdf

Timanus, E. (2005, March 4). Oklahoma investigates athletes' backgrounds. USA Today. Retrieved from https://advance.lexis.com/api/permalink/8e107bbc-8ff1-45f2-8409-883c503fbd84/?con$\underline{\text { text }=1516831}$

Title IX, 20 U.S.C.A. § 1681 (1972).

United Educators Insurance. (2015). Confronting campus sexual assault: An examination of higher education claims. Bethesda, MD: Author. Retrieved from http://www.ncdsv.org/ERS Confronting-Campus-Sexual-Assault_2015.pdf

U.S. Department of Education. (2016, May 9). Beyond the box: Increasing access to higher education for justice-involved individuals. Retrieved from https://www2.ed.gov/documents/beyondthe-box/guidance.pdf

Va. Code $\$ 23.1-407$ (2006).

Weissman, M., Rosenthal, A., Warth, P., Wolf, E., \& Messina-Yauchzy, M. (2010). The use of criminal history records in college admissions reconsidered. New York, NY: Author. Retrieved from http://www.communityalternatives.org/pdf/Reconsidered-criminal-hist-recs-in-college-admissions.pdf

Western, B., Schiraldi, V., \& Ziendenberg, J. (2003). Education \& incarceration. Washington, D.C.: Justice Policy Institute. Retrieved from http://www.justicepolicy.org/images/upload/03-08 REP_EducationIncarceration_AC-BB.pdf

Wyden, R., Merkley, J., Blumenthal, R., Smith, T., Murray, P., Wood Hassan, M., ... Markey, E. (2019, February 7). NCAA letter to Power 5 commissioners. Retrieved from https://www. wyden.senate.gov/imo/media/doc/NCAA $\% 20$ Letter $\% 20$ to $\% 20$ Power $\% 205 \% 20$ Commissioners. pdf

Young, B. R., Desmarais, S. L., Baldwin, J. A., \& Chandler, R. (2017). Sexual coercion practices among undergraduate male recreational athletes, intercollegiate athletes, and non-athletes. Violence Against Women, 23, 795-812. https://doi.org/10.1177/1077801216651339

Zimmerman, E. (2016, June 22). Campuses struggle with approaches for preventing sexual assault. The New York Times. Retrieved from https://www.nytimes.com/2016/06/23/education/campuses-struggle-with-approaches-for-preventing-sexual-assault.html 